\title{
JOHN BLACK FERGUSON WILSON
}

1883-1959

J. B. Ferguson Wilson died on June 24, 1959. He graduated M.B., B.S. in 1907 after a brilliant undergraduate career at Leeds University, later becoming M.S., London, and F.R.C.S.. England. He was on the resident staff of the Sheffield Royal Hospital from 1908 till 1912, when he was appointed Honorary Assistant Surgeon to the Hospital. He served on the Honorary Staff till 1943.

He was early attracted to orthopaedic surgery. and by the end of the first world war he was taking a special interest which increased throughout his surgical career, though he never ceased to be a general surgeon. At the invitation of Sir Robert Jones he joined the British Orthopaedic Association shortly after its foundation, and he maintained the greatest interest in it until his retirement, seldom missing any of its meetings.

Extremely widely read, he early became an authority on the literature of surgery. As a surgeon he was sound in diagnosis and conservative in treatment. Acknowledged by his colleagues to be a surgeon of the first rank, he never received the wider recognition which his talents merited, as he shrank from any form of publicity and from publishing. His great diffidence and

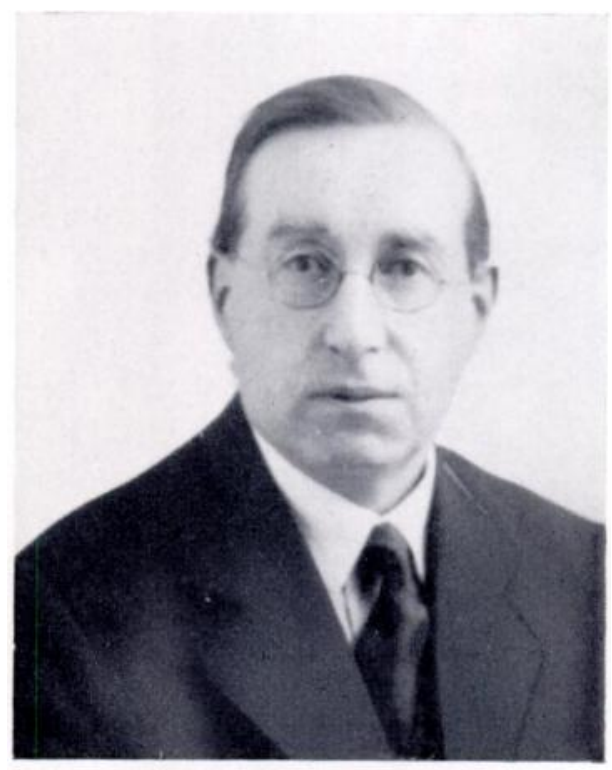
retiring disposition made him a difficult man to know intimately, but such was his character that he was held in affectionate regard and esteem by all his colleagues, and by everyone who knew him.

A. D.

\section{ALAN RUSCOE CLARKE}

1908-1959

On July 10, 1959, Ruscoe Clarke died suddenly but peacefully at Dudley Road Hospital in his first cardiac illness. He was that rare combination-an extremely busy experienced clinician and a research scientist. Whatever he undertook received his full attention. Ruscoe never wasted time.

Educated at Haileybury College, he entered Guy's Hospital in 1926. There, as a medical student. he won the Michael Harris Anatomy Prize, the Woolridge Physiology Prize and the General Proficiency Prize. In the year of his qualification he was placed proxime accessit for the Treasurer's Gold Medals in both medicine and surgery. A few months after qualifying he graduated M.B., B.S., of London University. Yet he found time to be secretary of Guy's Hospital Rugby Club and played in the first fifteen. Then, in the next five years, he held successive appointments at Guy's Hospital, and combined these with clinical assistantships at Great Ormond Street, All Saints' and St Peter's. One month after his twenty-fifth birthday he was elected a Fellow of the Royal College of Surgeons of England.

Awarded the Leverhulme Travelling Research Fellowship in 1936, he held clinical appointments at the Peter Bent Brigham Hospital and the Harvard Medical School. Here he 